\title{
A eSCRita de Si em Só de ANTÓNio Nobre
}

Tatiana Aparecida Picosque ${ }^{1}$

\section{RESUMO}

Este artigo pretende estudar a escrita de si na poética de António Nobre (1867-1900), analisando versos de seu livro mais conhecido, intitulado Só. Para a sua abordagem, escolhemos alguns dos profícuos momentos em que o autor entrelaça obra e biografia, o que, por sua vez, contribuiu para a construção de um efeito poético singular no cenário literário do fim do século XIX.

PALAVRAS-CHAVE: poesia portuguesa oitocentista; António Nobre; escrita de si.

\section{ABSTRACT}

This article intends to study the concept of self-writing in the poetry of Antonio Nobre (1867-1900), through the analysis of some poems from his best-known book, named Só. In order to do this, we chose some fruitful moments in which the author interlaces his fiction with his biography, which, in turn, contributed to the construction of a singular poetic effect in the literary scene of the end of nineteenth century.

KEYWORDS: Nineteenth-century Portuguese poetry; António Nobre; self writing.

\section{Lampejo biográfico}

Em 1867, nasce António Nobre na cidade do Porto. Quando atinge a vida universitária em 1889, ingressa no curso de Direito da Universidade de Coimbra, mas a sua personalidade excêntrica não encontra, a princípio, espaço nesse ambiente estudantil.

Depois de certo tempo, o poeta encontra amigos em Coimbra - principalmente a companhia de Alberto de Oliveira - que o admiram e com eles chega a fundar uma revista literária chamada Boémia Nova. A publicação não dura muito, mas acaba instaurando uma querela com outros poetas. A discussão faz surgir uma revista literária rival denominada Os Insubmissos e da qual participa o poeta simbolista Eugênio de Castro (1869-1944) - autor de Oaristos (1890), obra tida como marco inicial da estética simbolista na língua portuguesa. Os integrantes das duas revistas se insultam, discutem sobre a cesura dos alexandrinos, e António Nobre é tido pelos seus opositores como um "plagiador" de Guerra Junqueiro (1850-1923), um poeta extremamente popular naquela época. A discussão entre as duas revistas já anuncia o advento do Simbolismo em Portugal.

Voltemos à vida universitária de António Nobre em Coimbra. Temos que a sua situação se complica com duas reprovações consecutivas logo no primeiro ano da universidade. Além dos muitos alunos de Coimbra que o consideravam "excêntrico demais", percebe-se também que ele não fora bem aceito pelos professores de seu curso jurídico:

Se o poeta fosse um daqueles escolares apagados, respeitador das praxes convencionais da academia, a inteiro contento de lentes, de archeiros e de bedéis, é certo que a sua ciência seria suficiente, a somar à boa informação duma modesta e sossegada conduta, para lhe granjear as alturas dum nemine discrepante. (CASTILHO, 1980, p. 93)

\footnotetext{
${ }^{1}$ Doutoranda em Literatura Portuguesa (FFLCH/USP) sob a orientação da Prof ${ }^{a}$. Dr ${ }^{a}$. Marcia Arruda Franco e bolsista da FAPESP. E-mail: tatianapicosque@usp.br
} 
Decide, então, estudar Direito em Paris, na Sorbonne: "A saída de Portugal - para alcançar aquilo que Coimbra lhe negara - impusera-se como o único recurso, num país e numa época em que a carta de bacharel era o mínimo título capaz de abrir as portas de acesso à chamada vida prática" (CASTILHO, 1980, p. 98). E, em 1895, acaba por concluir o bacharelado em Direito na França.

Importante destacar a partida de António Nobre para a França, pois será neste país que o poeta publicará a primeira edição de seu livro mais conhecido, Só, em 1892. Ele consegue publicá-lo pela editora francesa Léon Vanier que, por sua vez, lançou obras de simbolistas franceses, tais como as de Paul Verlaine, Arthur Rimbaud e Stéphane Mallarmé. A ida a Paris lhe possibilitou o contato com os poetas simbolistas franceses, sobretudo Paul Verlaine.

Em 1898, publica-se a segunda edição de Só também por uma livraria francesa, agora pela Guillard, Aillaud. Há diferenças entre as duas edições francesas, pois a segunda irá aparecer revista e ampliada: mais poemas lhe são acrescentados; e encontramos "seções" que passam a agrupar os poemas, tais como "António", "Lusitânia no Bairro Latino", "Entre Douro-e-Minho", "Lua-Cheia”, "Lua QuartoMinguante", "Sonetos", "Elegias" e "Males de Anto", além do poema "Memória”, que funciona como abertura do livro.

Para fins de ensino de literatura, António Nobre é comumente estudado dentro do contexto da literatura simbolista portuguesa, embora encontremos em sua obra muitos elementos que, na verdade, tornam o escritor mais um precursor da poesia moderna - que, em Portugal, despontará mais tarde com Mário de Sá-Carneiro, Fernando Pessoa, entre outros.

Importante ainda apontar que António Nobre foi acometido pela tuberculose, e acaba por morrer no ano de 1900 com apenas 33 anos, após exaustivos tratamentos.

\section{Só, a recepção crítica oitocentista do "livro mais triste que há em Portugal"}

António Nobre confecciona os versos de Só praticamente entre 1891 e 1892, em Paris. A tiragem da primeira edição francesa limitou-se a cerca de trezentos exemplares, porém foi o bastante para difundi-lo e instaurar outro debate - lembremos de que o primeiro envolvendo o autor foi em razão da revista Boémia Nova.

Tal debate que agora se instaura diz respeito à recepção - nem um pouco amistosa - da primeira edição da obra pelo público oitocentista. O livro Só de António Nobre - cujo título seria Confissões contém poemas que confrontaram o "horizonte de expectativas" dos leitores do fim do século XIX. A obra foi objeto de inúmeras paródias, muitas vezes, anônimas. E as figuras portuguesas mais eminentes do período, por sua vez, foram implacáveis com o livro do jovem poeta; tratemos de citá-los: Pinheiro Chagas (demonstra radical incompreensão dos versos do poeta), Eça de Queirós (os versos nobreanos são tidos como extravagantes), Guerra Junqueiro (considerou os seus versos "secundários"), entre outros.

Quanto à primeira edição, podemos dizer que dentre os críticos consagrados, o único que reconhece o valor artístico de Só é Oliveira Martins (1845-1894) - isto foi considerado um verdadeiro trunfo por Alberto de Oliveira, amigo do poeta e defensor contumaz do valor literário da obra 
nobreana. Porém, temos notícias de que a segunda edição do Só, revista e publicada em 1898, recebeu críticas mais favoráveis:

De Lisboa chegam-lhe boas notícias: a $2^{\mathrm{a}}$ edição do seu livro já não é acolhida com a incompreensão e a indiferença irritante de que foi objecto a edição de Paris. Bastou o curto espaço de cinco anos para as coisas mudarem bastante. António Nobre já não é agora considerado o louco e cabotino, o oportunista duma poética passageira, como as "sumidades críticas" de 1892 na sua grande maioria alvitravam. (CASTILHO, 1980, p. 247)

No livro Só, António Nobre utiliza a sua biografia para compor muitos momentos de sua obra. A título de exemplo, encontramos no momento inicial do livro um longo poema intitulado António. Guilherme de Castilho, biógrafo do autor, parece considerar a personalidade excêntrica de António Nobre como a causa motriz de sua obra: "Faltando-lhe a presença estimulante de alguém que acredite nele, refugia-se na saudade do passado, no ensimesmamento do eu" (CASTILHO, 1980, p. 52-53). Hoje, sabemos que não é bem assim, já que o poeta construiu de modo astuto uma escrita de si.

Vejamos, no próximo tópico, trechos de poemas do autor, para que possamos entender a relação existente entre autobiografia e poesia em sua obra, bem como o seu modo de enunciação peculiar - e que faz com que muitos críticos o apontem como precursor da poesia moderna portuguesa.

\section{A escrita de si em poemas de Só}

Philippe Lejeune, ensaísta francês, conceitua a autobiografia como "narrativa retrospectiva em prosa que uma pessoa real faz de sua própria existência, quando focaliza sua história individual, em particular a história de sua personalidade" (LEJEUNE, 2008, p. 14). Numa primeira abordagem, Lejeune exclui o poema autobiográfico do rol de obras autobiográficas, já que a "forma da linguagem" da autobiografia deveria ser em prosa (e não em versos). Porém, o autor enuncia em outro estudo:

Em Le pacte autobiographique, afirmei - heresia! - que a autobiografia era "em prosa", o que, em 99\% dos casos ela é de fato, mas não certamente de direito. Foi inútil, depois disso, tentar me explicar longamente no mesmo volume (no capítulo intitulado "Michel Leiris. Autobiographie et poésie") ou voltar ao tema para apaziguar as coisas em 1986, em Moi aussi: as pessoas nos mandam calar o bico usando nossa própria definição (LEJEUNE, 2008, p. 86).

Para exemplificar o que pensa sobre a relação entre autobiografia e poesia, o ensaísta então comenta a respeito do escritor francês Michel Leiris (1901-1990):

Ele [Michel Leiris] estabelece aqui, entre poesia e autobiografia, na história de seus próprios escritos, uma relação de sucessão (uma depois da outra) e de oposição. Penso que é o inverso: ele fundiu, em um único e mesmo ato, poesia e autobiografia, e as faz caminhar juntas até o fim. Golpe de gênio que forneceu novas pistas que, até hoje, permanecem inexploradas. (LEJEUNE, 2008, p. 99-100)

Conforme Lejeune, portanto, é possível existir uma escrita de si em versos, ou seja, que autobiografia e poesia possam caminhar juntas: "Uma pode ser instrumento da outra. Não há mal 
nenhum em reconhecer que são duas coisas diferentes e, ao mesmo tempo, admitir-se a possibilidade de que têm muitas interseções” (LEJEUNE, 2008, p. 88).

Além dessas reflexões, sabemos que o ensaísta francês criou o conceito de pacto autobiográfico, formulado do seguinte modo:

O pacto autobiográfico é a afirmação, no texto, dessa identidade [do nome: autornarrador-personagem], remetendo, em última instância, ao nome do autor, escrito na capa do livro. As formas do pacto autobiográfico são muito diversas, mas todas elas manifestam a intenção de honrar sua assinatura (LEJEUNE, 2008, p. 26).

Em Só de António Nobre, como brevemente comentamos, tem-se vários poemas em que se constata a identidade entre o nome do autor-narrador-personagem, notadamente em António. Sobre esta relação entre autobiografia e obra, o crítico português Fernando Pinto do Amaral enuncia:

(...) a verdade é que existem autores cuja escrita depende mais diretamente da vida que lhe está subjacente, o que leva a que as suas coordenadas biográficas interfiram bastante no contorno das suas "coordenadas líricas" (como diria Fernanda Botelho). A figura de António Nobre corresponde, já se vê, a um extremo dessa influência, podendo mesmo dizer-se que se torna impossível abordar a sua obra sem que nessa abordagem se façam sentir os múltiplos ecos de um percurso biográfico tanto mais decisivo quanto acompanha a melodia de seus versos. Trata-se de um daqueles casos aos quais se adapta bem a asserção de Pierre Reverdy, para quem 'o valor de uma obra oscila na razão directa do contacto pungente do poeta com o seu destino'. (AMARAL, 1993, p. 77)

Dado que existe uma escrita de si nos poemas nobreanos, primeiramente, vejamos alguns dísticos do poema-abertura "Memória", no intuito de entrevê-la anunciada pelo sujeito:

\section{Memória}

Ora isto, Senhores, deu-se em Trás-os-Montes, Em terras de Borba, com torres e pontes.

Português antigo, do tempo da guerra, Levou-o o Destino pra longe da terra.

Passaram os anos, a Borba voltou,

Que linda menina que, um dia, encontrou!

Que linhas fidalgas e que olhos castanhos!

E, um dia, na Igreja correram os banhos.

Mais tarde, debaixo dum signo mofino, Pela lua-nova, nasceu um menino.

Oh mães dos Poetas! sorrindo em seu quarto, Que são virgens antes e depois do parto!

Num berço de prata, dormia deitado, Três moiras vieram dizer-lhe o seu fado

(E abria o menino seus olhos tão doces):

"Serás um Príncipe! Mas antes... não fosses". 
$[\ldots]$

E assim se criou um anjo, o Diabo, o lua:

Ai corre o seu fado! A culpa não é sua!

Sempre é agradável ter um filho Virgílio,

Ouvi estes carmes que eu compus no exílio,

Ouvi-os vós todos, meus bons Portugueses!

Pelo cair das folhas, o melhor dos meses,

Mas, tende cautela, não vos faça mal...

Que é o livro mais triste que há em Portugal!

(NOBRE, 2009, p. 51-52)

No poema, constatamos que o livro será, entre outras coisas, uma escrita de si. O sujeito poético nos relata que seu pai é de Borba, freguesia do norte de Portugal, e que descende de uma família portuguesa antiga, portanto, tradicional. O pai desse sujeito poético vivera muito tempo fora de Portugal. No plano biográfico, sabemos que o pai de António Nobre, José Pereira Nobre, morou, por conta de trabalho, cerca de vinte anos no Brasil. Depois, ele retorna a Portugal e casa-se com "uma linda menina”, isto é, a mãe do sujeito poético, a mãe de António Nobre - D. Ana de Sousa.

Casaram-se e, dessa união, nasce um menino, mais precisamente um poeta. Daí o verso: "Sempre é agradável ter um filho Virgílio". Este poeta, como podemos antever, trata-se de António Nobre. Curioso notar a identificação de Nobre com um poeta clássico, com o poeta latino Virgílio (70 a.C.-19 a.C.), já que isto prenuncia que a sua poética é fruto da leitura da tradição literária.

Só é um livro em que se verifica um maior despojamento da linguagem, uma aparente simplicidade que faz beirar um aparente confessionalismo — um eu que se desvela de modo quase infantil perante os leitores, o que pode levá-los a pensar que o autor escreveu o livro num "arroubo de inspiração", sem apuro formal. No entanto, ao equiparar-se ao poeta Virgílio, desconfiemos da aparente simplicidade da obra, estejamos atentos ao refinado trabalho poético existente por detrás desse aparente confessionalismo. Levemos muito em conta que o próprio sujeito poético nos pede em um dos seus versos: "Mas, tende cautela, não vos faça mal".

Logo após o nascimento do menino-poeta, temos a visita de "três moiras" que vêm anunciar o seu triste destino. Aqui, há um diálogo com a mitologia greco-latina, pois as três moiras (ou três Parcas, entre os romanos) tinham a função de determinar os destinos humanos e as quantidades de sofrimento atribuíveis a cada um. São as tecelãs do Destino.

As moiras vieram lhe anunciar: "Serás um Príncipe! / Mas antes... não fosses". Mais adiante, o eu é tido como "um anjo", "o Diabo" e "o lua", quer dizer, o bem, o mal, a loucura, todos juntos aparecem para compor a personalidade excêntrica do poeta. Qualificado como "o lua", o eu configura-se como alguém de comportamento estranho, arredio - quando comparado ao comportamento socialmente esperado. Temos, portanto, agregada ao eu poético a figura do "poeta maldito", quer dizer, do ser predestinado à arte, mas que, ao mesmo tempo, é um sofredor por sempre se encontrar à margem da sociedade - tal como um degredado, um incompreendido, um exilado. Daí justifica-se o verso "Ouvi estes carmes que eu compus no exílio"; é o sujeito poético pedindo ao leitor que ouça os 
carmes (versos líricos) compostos por ele no "exílio". E sobre a questão do exílio é pertinente o comentário que se segue:

Essa assunção do exílio como inerente à condição poética, que do Romantismo transitara para os poetas anunciadores da Modernidade - num rasto que vai de Victor Hugo ao baudelairianismo, ou entre nós de Herculano ao "neogarretismo" finissecular - encontra no Simbolismo a sua expressão mais sublimada, liberta já da referencialidade histórica ou da subjectividade psicológica, para se hipostasiar na figura, na persona mesma do poeta. (SEABRA, 1994, p. 219)

Em suma, a personalidade delineada no poema é a de um eu português, poeta, predestinado a um destino infeliz, escritor do livro "mais triste que há em Portugal", o Só. Ele também é um "Príncipe" — marginalizado, porém alguém superior, e conforme enunciou um crítico português:

E, de facto, foi príncipe. Nobre reinou sobre si mesmo e sobre o seu próprio passado. Reinou afinal sobre tudo aquilo que o homem pode dizer afoitamente que é seu: o seu próprio mundo espiritual. Quem poderia impedir Nobre de ser príncipe num reino cujas fronteiras eram a sua imaginação e a sua memória. Sobre a imaginação e a memória é dado ao homem reinar omnipotentemente. Nunca lhe será dado porém reinar sobre o porvir. (SIMÕES, 1939, p. 27)

Deparamo-nos assim com um eu cuja imagem é a de um "poeta maldito". Mas, paradoxalmente, essa predestinada maldição anunciada pelas três moiras torna o seu eu excelente, meritório, principesco, aristocrático, enfim, "nobre" (o que coincide com o sobrenome do autor do livro: Nobre).

O título do poema, como vimos, é "Memória". Mais interessante é notarmos o propósito da evocação da memória no livro, por este eu fadado à infelicidade:

Tiranizado pelo Tempo, só resta a António Nobre fugir dele paradoxalmente pelo tempo, mas numa dimensão diferenciada, qual seja: a da memória afetiva $[\ldots]$. António Nobre adota um dos procedimentos mais caros à estética simbolista, que é a capacidade de evocar [...]. Ou seja: o fim último da poesia não é o objeto, mas um estado de alma, inapreensível em si e somente recuperável pelo poder da evocação. Não é à toa, portanto, que a presença do vocativo seja uma constante na poesia de António Nobre [...]. O processo evocativo torna-se o meio mais adequado de se recuperar o que se perdeu, ou seja, fazer que o tempo passado se materialize no presente ou se torne ele mesmo presente, depois da ativação dos conteúdos da chamada "memória involuntária" (GOMES, 2002, p.131-136).

Após "Memória", somos contemplados com o longo poema intitulado "António", texto em que podemos vislumbrar o desenvolvimento da memória afetiva do sujeito acima mencionado pelo crítico Álvaro Cardoso Gomes. O poema "António" é bem mais extenso do que os trechos que transcreveremos, mas o nosso intuito é apresentar a questão que vimos tratando até aqui, a saber, o delineamento de uma escrita de si no poema, por meio de rememorações do sujeito poético que incluem o percurso de sua infância à idade adulta. Então, leiamos alguns de seus trechos:

\footnotetext{
${ }^{2}$ Nele, o sentido da leitura surge do diálogo entre os dísticos e os tercetos, paralelamente ao das quadras.
} 
Que noite de Inverno! Que frio, que frio!

Gelou meu carvão:

Mas boto-o à lareira, tal qual pelo estio,

Faz sol de verão!

Nasci, num Reino d'Ouro e amores, À beira-mar.

Ó velha Carlota! Tivesse-te ao lado,

Contavas-me histórias:

Assim... desenterro, do Val do Passado, As minhas Memórias.

Sou neto de Navegadores,

Heróis, Lobos d'água, Senhores

Da Índia, d'Aquém e d'Além-mar!

[...]

Erguei-vos, defuntas! da tumba que alveja

Qual a Lua, à distância!

Visões enterradas no adro da Igreja

Branquinha, da Infância.

$$
\text { [...] }
$$

Lá vem Carlota que embala uma aurora

Nos braços, e diz:

"Meu lindo Menino, que Nossa Senhora

O faça feliz"

$$
\begin{aligned}
& \text { Ao Mundo vim, em terça-feira! } \\
& \text { Um sino ouvia-se dobrar! }
\end{aligned}
$$

E António crescendo, sãozinho e perfeito,

Feliz que vivia!

(E a Dor, que morava com ele no peito,

Com ele crescia... )

$$
\text { [...] }
$$

E entrei para a escola, meu Deus! quem me dera

Nessa hora da Vida!

$$
\text { [...] }
$$

E os anos correram, e os anos cresceram,

Com eles cresci:

Os sonhos que tinha, meus sonhos... morreram,

Só eu não morri...

Fui vendo que as almas não eram no Mundo

Singelas e francas:

A minha, que o era, ficou num segundo

Cheiinha de brancas!

Cortai-me as barbas e o cabelo, Vesti-me esse hábito singelo... Deixai-me entrar!

Fiquei pobrezinho, fiquei sem quimeras,

Tal qual Pedro-Sem,

Que teve fragatas, que teve galeras,

Que teve e não tem...

Moço lusíada! Criança!

Por que estás triste, a meditar?

Vieram as rugas, nevou-me o cabelo

Qual musgo na rocha...

Fiquei para sempre sequinho, amarelo,

Que nem uma tocha!

Vês teu país sem esperança, 


\author{
Que todo alúi, à semelhança \\ Dos castelos que ergueste no Ar? \\ E a velha Carlota, revendo-me agora \\ Tão pálido, diz: \\ "Meu pobre Menino! que Nossa Senhora \\ Fez tão infeliz..."
}

(NOBRE, 2009, p. 57-68)

Paris, 1891.

No início do poema, o eu enuncia que "Nasci, num Reino d'Ouro e amores, / À beira-mar", ou seja, trata-se, como vimos no poema "Memória", de um português. Encontramos, mais que isso, a evocação de Portugal dos séculos XIV e XV com os versos "Sou neto de Navegadores,/Heróis, Lobos d’água, Senhores/Da Índia, d’Aquém e d'Além-mar”. O eu tem como antepassados os grandes navegadores portugueses, tidos por "heróis”. Tem, portanto, um passado nobre e glorioso.

Em seguida, constatamos a evocação de Carlota, "nome da empregada que trabalhou durante muitos anos na casa da família de António Nobre” (FERNANDES; GARMES, 2009, p. 68). Como já mencionamos, o eu regressa à sua infância, ao seu passado, por meio de uma memória afetiva da qual Carlota faz parte. Esta "embala uma aurora nos braços”, ou seja, o eu do poema quando então era um recém-nascido. Carlota lhe contava histórias, sendo que o sujeito poético também deseja nos contar as suas "Memórias", ou melhor, efetuar o "desenterro, do Val do Passado". E, para tanto, as evoca com os versos: "Erguei-vos, defuntas! da tumba que alveja" e "Visões enterradas no adro ${ }^{3}$ da Igreja/Branquinha, da Infância”.

Carlota, a ama que carrega em seus braços o sujeito na sua mais tenra infância, enuncia: "Meu lindo Menino, que Nossa Senhora/ O faça feliz”. Aqui, destaca-se a religiosidade tipicamente católica em que este eu se verá educado. Em seguida, o dístico "Ao Mundo vim, em terça-feira!/ Um sino ouvia-se dobrar!" vem quebrar a proteção divina solicitada a favor do menino pela crente Carlota. O sujeito poético nos afirma que nasceu numa "terça-feira”, ou seja, num dia considerado de mau agouro pelos portugueses mais supersticiosos. Portanto, de nada adiantará o pedido de Carlota — lembremo-nos de que no poema-abertura "Memória", as três moiras (o que remete a um paganismo) já tinham anunciado o triste fado do poeta.

No final do poema "António", encontramos uma quadra, absolutamente irônica, que confirma o não atendimento do pedido da fervorosa Carlota: "E a velha Carlota, revendo-me agora/ Tão pálido, diz:/ “Meu pobre Menino! que Nossa Senhora/ Fez tão infeliz...”. Quer dizer, a criança tornou-se um adulto triste, pálido, melancólico.

No transcorrer do poema, o sujeito nos relata o seu crescimento, enuncia que a saúde de seu corpo esconde uma melancolia latente, ou melhor, como vai a "a saúde de sua alma”, "a saúde de seu

\footnotetext{
${ }^{3} \mathrm{O}$ adro refere-se a um pátio externo em torno de uma Igreja ou a cemitério situado no terreno de antigas igrejas. $\mathrm{Na}$ quadra do poema, o sentido de "adro" é o de cemitério, que, por sua vez, serviu de enterro para as visões pertencentes ao passado, à infância do sujeito. Em nossa análise, não exploraremos a diálogo intertextual existente no poema com a obra de Luís Vaz de Camões. Porém, é curioso notar que este poeta quinhentista foi enterrado num adro de uma Igreja, em Portugal.
} 
eu”. E daí os versos: "E António crescendo, sãozinho e perfeito,/ Feliz que vivia!/ (E a Dor, que morava com ele no peito,/ Com ele crescia...)”. Salientemos que o uso recorrente de diminutivos por António Nobre em sua obra foi muito criticado, alegando-se uma imaturidade, uma ingenuidade do poeta. No entanto, o emprego ostensivo de diminutivos é, na verdade, uma estratégia discursiva para construir uma memória afetiva referente a esse eu ensimesmado e, principalmente, para construir uma boa dose de ironia - e isto tornará o texto inteligente, crítico, e não ingênuo ou sentimentaloide, como muitos alegaram.

No poema, deparamo-nos com os versos "Os sonhos que tinha, meus sonhos... morreram,/ Só eu não morri...", quer dizer, a "saúde do eu" se encontra completamente abalada quando este atinge a idade adulta. O eu lamenta-se de sua desilusão e de ter-lhe restado apenas o seu interior vazio. Vislumbramos em outros versos a construção de um eu que deseja se enclausurar tal como um monástico, que deseja se recolher à sua intimidade; citemos então estes versos: no dístico "Frades do Monte de Crestelo!/ Abri-me as portas! Quero entrar...” e, no terceto que dialoga com o dístico citado “Cortai-me as barbas e o cabelo, / Vesti-me esse hábito singelo.../ Deixai-me entrar!".

Quando analisamos o livro Só procurando por sua organicidade, evidenciada no percurso do sujeito do poema "Memória a Males de Anto", percebemos que a escrita de si envolve um entrelaçamento entre o que podemos chamar "eu individual" e "eu coletivo". Conforme esta perspectiva, transcrevamos um comentário sobre as seções encontráveis a partir da segunda edição da obra, em 1898:

É possível dizer que todos os poemas do livro traçam um percurso do eu-poético. Tal percurso partiria do eu-poético coletivo Antônio para o eu-poético existencial Anto. Definido nos dois primeiros poemas do livro ["Memória" e "António"] como um exilado e, portanto, predominando o sentido social e político dessa figura, Antônio caminhará no decorrer do livro para uma perspectiva mais intimista e existencial de Anto, sem abandonar o sujeito socialmente definido (...). A partir de "Lua QuartoMinguante" e depois em "Sonetos", "Elegias" e "Males de Anto", a roupagem social do eu-poético começa a perder expressão, mantendo, todavia, a perspectiva intimista, presente desde o início do livro. A partir daqui, acentua-se o perfil familiar, existencial e mesmo psicanalítico do eu-poético, recolhido cada vez mais em espaços de intimidade: a torre, o quarto, a cova. (FERNANDES; GARMES, 2009, p. 27-30)

No poema "António", configura-se de modo mais explícito a relação do sujeito com a coletividade, com o país ao qual pertence: Portugal. Este eu ensimesmado, que deseja nos expor os fatos de sua vida e as suas aflições, desnuda-se ao leitor e, ao mesmo tempo, desnuda o seu país em fins do século XIX:

Uma vez convictamente assumida e eficazmente imposta (através da enunciação aparentemente mais cândida) a equação decisiva - “... que falo só de mim. Mas não sou eu o intérprete das dores do meu País? -, o Só garante de novo o passe de mágica dúplice: tudo o que revelar do narcisismo (do tropismo narcísico, da pose narcísica, do corroído mito de Narciso) vale para a revelação espectral aos "bons Portugueses" do estado da nação, da alma e do destino pátrios (PEREIRA, 1993, p. 35).

\footnotetext{
${ }^{4}$ Abreviatura do nome do autor, António. Foi dado por Miss Charlotte, um dos amores do poeta.
} 
Dessa maneira, temos condições de compreender a quadra "Fiquei pobrezinho, fiquei sem quimeras,/ Tal qual Pedro-Sem ${ }^{5}$,/ Que teve fragatas, que teve galeras,/ Que teve e não tem...”; o dístico "Moço lusíada! Criança!/Por que estás triste, a meditar?"; e, por fim, o terceto "Vês teu país sem esperança,/ Que todo alúi, à semelhança/ Dos castelos que ergueste no Ar?". Nestes trechos, vislumbramos o entrelaçamento do sujeito poético com o "eu coletivo" — como português, o eupoético é herdeiro da cultura portuguesa. Aqui, António Nobre acentua a tragicidade do sujeito poético revelando, paralelamente, signos da decadência de seu país presente. Portugal, como sabemos, teve um passado glorioso - o período das Grandes Navegações — mas, no período oitocentista, encontra-se abalado e atrasado com relação a outros países europeus. Encontra-se só, tal qual o sujeito poético, tal qual o título sugestivo do livro.

O crítico português, porém, alerta que nos poemas de António Nobre assistimos à coexistência de um Portugal oitocentista decadente, mas, ao mesmo tempo, detentor de belezas. Não encontramos apenas um mero contraste entre o Portugal quinhentista — das Grandes Navegações — e o Portugal oitocentista — sem relevância econômica dentro do contexto econômico finissecular —-, no intuito de ressaltar as suas mazelas do presente:

A diagnose da condição portuguesa e da condição humana finissecular cumpre-se pela contrastada fisionomia de grandeza e decadência (não tanto pela evocação de glórias passadas e falências presentes quanto pela coexistência de signos e vivências de pujança e de declínio) e pela contrastada descrição do país das misérias e das maravilhas, das chagas e dos encantos, das pobrezas e das belezas (PEREIRA, 1993, p. 36).

Por fim, Annie Gisele Fernandes, que se dedica a relevantes estudos sobre a poética de António Nobre, assevera que

o poema António é o mais complexo e o mais significativo dos poemas de estrutura dialógica, pois nos dá a conhecer um sujeito poético multifacetado, no qual se destaca a existência de vários "eus" [...] através do contraponto entre as vozes são revelados, entre outras coisas, os vários "eus" de um "eu", os vários sujeitos poéticos que compõem a personalidade poética de António Nobre, o vate que pode apontar, com esse procedimento e de maneira ainda que muito incipiente, a poética dos heterônimos de Fernando Pessoa. (FERNANDES, 2002, p. 60)

Em Só, nos deparamos com a construção de um retrato íntimo entrelaçado a um retrato nacional — ou "a dupla face de um retrato duplo" como bem define o crítico José Carlos Seabra Pereira. No soneto 13 do livro, há espaço para o convívio com os outros, portugueses ou não:

Falhei na vida. Zut ${ }^{6}$ ! Ideais caídos!

Torres por terra! As árvores sem ramos!

Ó meus Amigos! todos nós falhamos...

Nada nos resta. Somos uns perdidos.

Choremos, abracemo-nos, unidos!

Que fazer? Por que não nos suicidamos?

Jesus! Jesus! Resignação... Formamos

No mundo, o Claustro-pleno dos Vencidos.

\footnotetext{
${ }^{5}$ Pedro-Sem significa uma pessoa sem rumo.

${ }^{6}$ Interjeição francesa que exprime irritação.
} 
Troquemos o burel ${ }^{7}$ por esta capa!

Ao longe, os sinos místicos da Trappa ${ }^{8}$

Clamam por nós, convidam-nos a entrar:

Vamos semear o pão, podar as uvas,

Pegai na enxada, descalçai as luvas,

Tendes bom corpo, Irmãos! Vamos cavar!

(NOBRE, 2009, p. 209)

Nas quadras, o eu-poético afirma "Falhei na vida", “Ó, meus Amigos! todos nós falhamos" e "Somos uns perdidos", quer dizer, o sentimento de derrota que acomete o sujeito poético acaba se estendendo aos outros — considerados os seus "Amigos" e "Irmãos" ao longo do soneto. Nos tercetos, o derrotismo das quadras esvai-se e cede lugares ao vigor e à solidariedade, o que relativiza a decepção do sujeito tecida no poema "António", em versos como "Fui vendo que as almas não eram no Mundo/ Singelas e francas:/ A minha, que o era, ficou num segundo/ Cheiinha de brancas!”.

Neste soneto, a atitude solidária — e não solitária — do sujeito faz reputarmos a seu isolamento social um ato quase involuntário. O sujeito, vimos em "Memória", é um poeta. Comumente, as atitudes daqueles que se dedicam à arte são recriminadas pela sociedade, pois são tidas por excêntricas, estranhas, incomuns. Infelizmente, os que se entregam aos preconceitos contra o artista acabam estereotipando-o como o louco, o pálido, o melancólico, o instável, o Diabo, o lua... Interessante salientar que o sujeito poético, neste soneto, deixa claro que todos - e não só ele — pertencem a uma sociedade fracassada, guiada por uma visão de mundo extremamente utilitária e conservadora. E todo indivíduo, como o poeta António, que destoe da normalidade preestabelecida será execrado, "convidado" a recolher-se à sua intimidade, a conviver minimamente com os outros. Ele, António-poeta, é elemento de instabilidade no seio da sociedade. É um corpo estranho; a sociedade o recusa e, como autodefesa para a sua rica individualidade, ele a recusa também. António faz parte do grupo de "poetas aristocráticos", falsamente tidos como desinteressados pela sociedade, dado que comumente são repelidos por ela.

Façamos uma pequena digressão com relação à análise do soneto 13. Em "Males de Anto", poema final do livro, fica patente o preconceito de Carlota — personagem do âmbito popular — com relação à vida de poeta de António, agora um adulto. Num diálogo com a Senhora Júlia — outra personagem do âmbito popular, Carlota chega a apontar como causa do sofrimento íntimo de António o convívio com a arte:

E se eu falasse à Ana Coruja, essa que bota - Ó Sra Carlota,

As cartas? Foi talvez malzinho que lhe deu...

- Nunca foi assim: foi depois que se meteu

A fumar, a beber e lá com as po'sias.

$$
[\ldots]
$$

\footnotetext{
${ }^{7}$ Nome de tecido grosseiro de lã, geralmente de cor escura. Hábitos de frades e freiras feitos com este tecido.

${ }^{8} \mathrm{O}$ termo "Trappa" refere-se à abadia beneditina de Notre-Dame de la Trappe, em Soligny, situada na França, fundada em 1140, e que originou a ordem dos trapistas.
} 


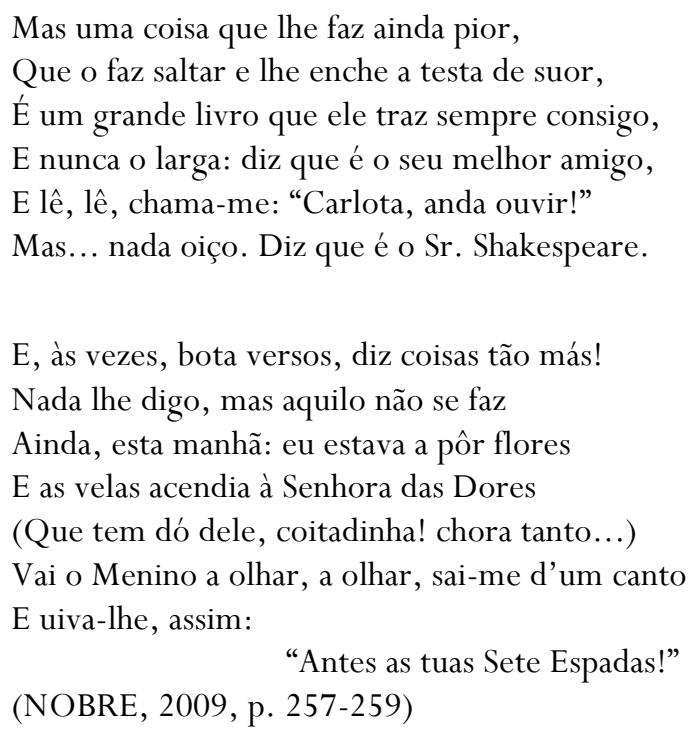

Carlota gosta de António e intercede por ele aos santos. Porém, considera o seu ofício de poeta imoral e até demoníaco: António “diz coisas tão más" e “aquilo não se faz". Carlota, ao dizer "e lhe enche a testa de suor”, sugere-nos uma possessão demoníaca. A ama de António completa a sua descrição preconceituosa quando toma o entusiasmo de António ao versejar “Antes as tuas Sete Espadas" por loucura, já que o "Menino uiva”, tal como um animal medonho, perigoso.

O sujeito poético não deixa por menos e tece duras críticas à religiosidade de Carlota em versos de "Males de Anto"; vejamos um desses momentos: "A Carlota! A Carlota!/ Boa velhinha, como ela é meiga e devota!/ Já estaria bem, se me valessem rezas" (NOBRE, 2009, p. 255). Com "Males de Anto", percebemos que a escrita de si envolve a imagem estereotipada proveniente dos outros, percebemos que este eu ensimesmado, aristocrático, funciona como capa protetora contra o preconceito dos que não o compreendem.

Ao contrário do poema "António", em que o sujeito afirma ser a sua "alma” singela e franca e as dos outros não, vislumbramos no soneto 13 o anseio do eu pela comunhão com o outro. Principalmente nos tercetos, desvela-se um eu anfitrião, crente na solidariedade humana e na comunhão com a natureza: "Vamos semear o pão, podar as uvas, / Pegai na enxada, descalçai as luvas, / Tendes bom corpo, Irmãos! Vamos cavar!”

Curiosas são as imagens referentes ao "burel" e "aos sinos místicos da Trappa", por sinal, essenciais ao entendimento do soneto. Quando o sujeito poético enuncia "Troquemos o burel por esta capa!/ Ao longe, os sinos místicos da Trappa/ Clamam por nós, convidam-nos a entrar”, ele pretende refutar a resignação, o conformismo, o conservadorismo, e o próprio isolamento que os homens — os seus Irmãos - impõem a ele enquanto poeta. O burel, roupa escura e típica de frades, deve ser trocado por uma “capa”. Talvez, esta capa se refira à roupa clara que bem caracteriza as vestes dos monges trapistas. Estes pertencem a uma ordem religiosa que segue a Regra beneditina, cujos membros vestem hábitos brancos — por excelência, a cor da comunhão — e vivem em comunidade praticando a atividade agrícola — daí as referências no poema ao pão, às uvas, à enxada, ao corpo, às luvas e ao cavar.

\footnotetext{
${ }^{9}$ Alusão aos versos do poeta português Almeida Garrett (1799-1854), muito apreciado por António Nobre.
} 
Todos os mosteiros trapistas se sustentam do próprio trabalho, sendo os bens comunitários, e alguns vivem de fabricação de cerveja. Os monges se dedicam ao trabalho manual, ao estudo e ao silêncio, no intuito de autoconhecimento e da comunhão com Deus, e daí a expressão "sinos místicos da Trappa" no poema. Vivem em clausura, mas têm rigorosas obrigações dentro da comunidade monástica à qual pertencem.

No soneto, enfim, o sujeito poético explicita a sua vontade de ir ao encontro dos outros. Ele é um recluso, por querer a comunhão com a arte, porém isto não implica o seu esquecimento quanto às mazelas sociais, quanto ao sofrimento humano em geral. Num poema importantíssimo do livro, chamado "Lusitânia no Bairro Latino"10 , a escrita de si novamente constrói a figura do poeta maldito que, por seu turno, identifica-se com a dos excluídos:

Ó minha capa de estudante, às ventanias! $[\ldots]$

Tísicos! Doidos! Nus! Velhos a ler a sina! Etnas de carne! Jós! Flores! Lázaros! Cristos! Mártires! Cães! Dálias de pus! Olhos-fechados! Reumáticos! Anões! Deliriums-tremens! Quistos! Monstros, fenómenos, aflitos, aleijados, Talvez lá dentro com perfeitos corações: Todos, a uma, mugem roucas ladainhas, Trágicos, a uma, mugem roucas ladainhas, Trágicos, uivam "uma esmolinha p'las alminhas Das suas obrigações!" Pelo nariz corre-lhes pus, gangrena, ranho! E, coitadinhos! fedem tanto: é de arrasar...

Qu'é dos Pintores do meu país estranho, Onde estão eles que não vêm pintar? (NOBRE, 2009, p. 76-84)

A identificação entre sujeito poético e estes desafortunados torna-se evidente pelo termo "uivam", já que vimos Carlota, no poema "Males de Anto", afirmar que António uivava quando declamava versos. A preocupação com os excluídos, inclusive ele, fica patente nos dois últimos versos, visto que o sujeito tece críticas aos "Pintores" que fecham os olhos aos problemas sociais, retratando em seus quadros apenas panoramas sem consciência crítica.

\section{Considerações finais}

No livro Só, a escrita de si configura-se de modo muito complexo. António Nobre aproveita o seu percurso biográfico para transfigurá-lo em arte, conduzindo sempre juntas a autobiografia e a poesia, bem ao gosto do que afirmou Philippe Lejeune acerca da obra de Michel Leiris.

António Nobre utiliza nomes de pessoas queridas e conhecidas que fizeram parte de sua vida, menciona os locais vividos na infância e nos tempos de estudante, entrelaça a sua vida com a de seu país, aproveita aspectos de sua personalidade "excêntrica" para compor um eu melancólico, narcísico, mas

\footnotetext{
${ }^{10}$ Referência explícita ao Quartier Latin - célebre bairro francês em que moravam os estudantes.
} 
irônico, no livro. O mito de Narciso chega a ser evocado no livro — se bem que parodiado, já que o eu enunciativo foge de si mesmo em vez de se enamorar pela própria imagem —, em "Males de Anto":

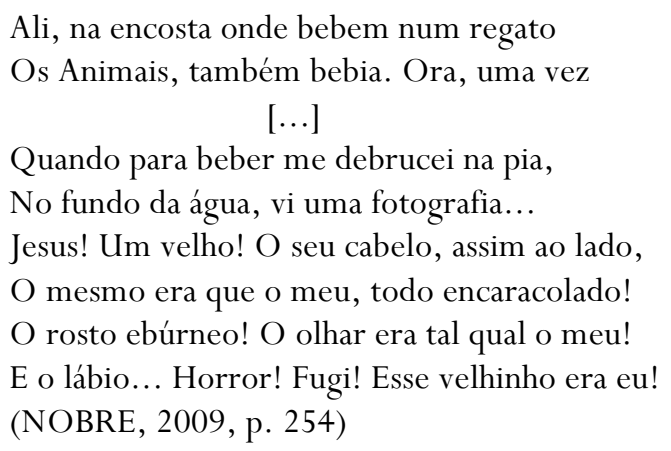

Em Só, relata-nos o seu nascimento, o seu percurso existencial e, finalmente, na primeira parte do poema final "Males de Anto", apresenta-se como um portador de "Tísica d'Alma", tal como um doente em estado grave. Na segunda parte "Meses depois, num cemitério", encontramos o sujeito poético, o Anto, procurando por um lugar que lhe sirva de repouso eterno. Anto pergunta ao coveiro: “Olá, bom velho! É aqui o Hotel da Cova,/ Tens algum quarto ainda para alugar?". O coveiro lhe responde: "Os quartos, meu Senhor, estão tomados,/ Mas se quiser na vala (que é de graça...)/ Dormem, ali, somente os desgraçados” (NOBRE, 2009, p. 260). António Nobre, neste poema escrito em 1891, simula a própria morte por tuberculose (se bem que é uma tísica d'alma), doença muito comum no século XIX e que, por ironia, irá vitimá-lo em 1900. Portanto, aqui, trata-se de uma biografia inventada, o que indica que não devemos nos fiar numa estreita relação entre obra e biografia.

Maria Heloísa Martins Dias tece reflexões, com as quais compactuamos, sobre a obra nobreana em geral:

\footnotetext{
Focar a si mesmo - eis o princípio que funda projeto poético de António Nobre, uma focagem por demais explícita para ser tomada apenas como transparência [...] propõe-se uma sensibilidade perturbadora, um desdobramento estratégico criado pelo poeta, espécie de heterônimo à maneira pessoana, mas, ao contrário do Pessoa desdobrável em múltiplos eus, o "Anto" se ergue como figura única, como centro de um universo. Digamos que se trata de um ortônimo heteronimizado, cuja autobiografia se ficcionaliza por meio de um simulacro para falar de si mesmo: o mesmo é o outro trazido pela linguagem (DIAS, 2002, p. 68-69).
}

O leitor deve ser prudente a ponto de captar o jogo entre aproximação e distância que se instaura na imagem que o poeta constrói de si mesmo. Há um discurso subjacente ao discurso enunciado, e o leitor tem de notar essa ironia que perpassa o Só. Por um lado, tem-se a todo tempo um eu poético que utiliza o discurso religioso, mas que, sobretudo, intenta criticar a fé ingênua e fervorosa das pessoas com quem convive. Por outro, os diminutivos que denotam aproximação e afetividade no enunciado desencadeiam, por sua vez, a distância e a zombaria pelo eu enunciativo, contribuindo para a ambiguidade do discurso poético. Vimos que Carlota era uma figura afetiva, mas também alvo de escárnio por conta de sua religiosidade. E assim sucederá com todos os outros diminutivos que, por seu turno, carregam sempre uma primeira leitura mais superficial, ocultando uma outra mais profunda e normalmente imbuída de sarcasmo, rebeldia, crueldade, crítica, entre outros aspectos. Por isso, Maria 
Heloísa Martins Dias chega a considerar António, enquanto eu poético, um “ortônimo heteronimizado", já que ele elege como estratégia discursiva sempre o foco em si mesmo — daí o ortônimo —, mas, ao mesmo tempo, ele nos surge como "outros", quando uma leitura mais atenta, que contemple a ironia dos termos de seu discurso, é levada a cabo pelo leitor — daí a expressão heteronimizado.

Portanto, há duas grandes leituras possíveis do livro e que vêm caracterizar o próprio modus operandi da ironia: a primeira leitura diz respeito ao simples entendimento daquilo que literalmente foi afirmado, e a segunda, por sua vez, compreende os sentidos subentendidos que acabam por desestabilizar a primeira leitura, tornando o texto altamente crítico.

Por fim, António Nobre enreda biografia e obra, confeccionando um texto de refinada ironia, em que o eu já é outro, ou outros, anunciando uma poética da alteridade que a Modernidade, mais tarde, tornará regra máxima. 


\section{Referências bibliográficas}

AMARAL, F. P. “A poesia como doença da alma: uma abordagem do 'spleen' no Só”. COLÓQUIO/Letras, Lisboa, número 127/128, p. 77-86, 1993.

CASTILHO, G. Vida e obra de António Nobre. 3ª ed. Lisboa: Livraria Bertrand, 1980.

DIAS, M. H. M. “António, Anto, o Santo: ficções irônicas tramadas pela linguagem poética”. Voz Lusíada, São Paulo, número 17, p. 67-81, 2002.

FERNANDES, A. G. "As inovações estético-formais do Só de António Nobre e a fortuna crítica”. Estudos Portugueses e Africanos, Campinas, número 39, p. 53-66, 2002.

GOMES, A. C. "Memória e evocação em António Nobre”. Voz Lusíada, São Paulo, número 17, p. 126136, 2002.

LEJEUNE, P. "Parte I. O pacto autobiográfico”. In: LEJEUNE, P. O pacto autobiográfico: de Rousseau à Internet. Trad. Jovita Maria Gerheim Noronha; Maria Inês Coimbra Guedes. Belo Horizonte: UFMG, 2008, p. 13-109.

NOBRE, A. Só - seguido de Despedidas. Apresentação e notas Annie Gisele Fernandes, Helder Garmes; ilustrações Marcelo Salum. São Paulo: Ateliê, 2009.

PEREIRA, J. C. S. “A dúplice exemplaridade do Só”. COLÓQUIO/Letras, Lisboa, número 127/128, p. 27-44, 1993.

SEABRA, J. A. Poligrafias poéticas. Porto: Lello \& Irmão, 1994.

SIMÕES, J. G. António Nobre, precursor da poesia moderna. Lisboa: Inquérito, 1939.

Artigo recebido em: 30/01/2010

Artigo aprovado em: 20/02/2010

Referência eletrônica: PICOSQUE, Tatiana Aparecida. A escrita de si em Só de António Nobre, Revista Criação \& Crítica, n. 4, p. 36-51, 2010. Disponível em:

<http://www.fflch.usp.br/dlm/criacaoecritica/dmdocuments/04CC_N4_TPicosque.pdf> 